\title{
RESEARCH
}

Open Access

\section{Farmers' perceptions on cultivation and the impacts of climate change on goods and services provided by Garcinia kola in Nigeria}

Onyebuchi Patrick Agwu ${ }^{1 *}$, Adama Bakayoko², Saka Oladunni Jimoh³ and Porembski Stefan ${ }^{4}$

\begin{abstract}
Background: Garcinia kola is an indigenous multipurpose tree species commonly found in the tropical rain forest zone of West and Central Africa. Providing economic, ecological, and socio-cultural benefits for people, they have potentials to improve the regional and local income generation to the farmers but the cultivation of the species is very limited in Nigeria.
\end{abstract}

Methods: The study investigated cultivation and farmers' perceptions on the impacts of climate change on goods and services provided by G. kola in Nigeria. Structured questioners and interviews were used. The data obtained was analyzed using descriptive and inferential statistic such as frequency, percentage, chi-square, and multinomial logit regressions with SPSS Version 20 and R software Version 3.1.0.

Results: The results show that farmers are presently not cultivating $G$. kola, and most of the available stands were inherited from grandparents. The farmers still believe it is only God that can make G. kola to germinate; however, information about the new improved methods of raising G. kola was not spread across farmers' communities. Over 93\% of these farmers were not aware of these new methods, and the only means they raise the species is by picking the wildlings that regenerate naturally close to mother tree and are rarely found. The finding also shows that farmers are well aware of climate change and its impact on crop productivity is not clear to them. The result shows that five explanatory variables (age, gender, marital status, education level, household size and primary occupation) are the main factors significantly influencing farmers' perception of climate change and the cultivation of the G. kola. During interview section, the farmers reported variability of Harmattan season influences fruit production of the species; according to them, increase in Harmattan season usually leads to increase in fruiting of G. kola.

Conclusions: Based on our findings, all the 215 respondent interviewed agree that climatic variability influences the availability of $G$. kola which will in turn have significant effects on the goods and services provided to the people. Efforts should be made at educating the rural farmers on propagation possibilities, potential ecosystem services, and the impact of climate change on multiple-purpose agroforestry species.

Keywords: Garcinia kola, Propagation, Multipurpose species, Farmers, Climate change, Harmattan season

\footnotetext{
* Correspondence: agwu.o@edu.wascal.org

'WASCAL Graduate Research Program on Climate Change and Biodiversity,

Universite' Felix Houphouet Boigny, BP 165, Abidjan 31, Côte d'Ivoire

Full list of author information is available at the end of the article
} 


\section{Introduction}

In many African countries, economies are largely based on weather-sensitive agricultural and forest fruits production systems which are vulnerable to climate change (Dinar et al. 2006). The Intergovernmental Panel on Climate Change (IPCC 2014) and Niang et al. (2014) reported that the Africa region is one of the major areas of the world most vulnerable to the impacts of climate change. Previous studies have shown that climate change has significant impacts on crop yields (IPCC 2007; Deressa et al. 2008).

Climate change is increasingly one of the most serious national security threats which will have significant impacts on natural resources, ecosystems, and biodiversity, and at the same time, it is likely to trigger food insecurity and decrease plants' productivity and availability. Enete (2004) reported that the actual and potential impacts of climate change in Nigeria are having far-reaching effects on agriculture. All sectors of socio-economic development, including forestry and agriculture, are vulnerable to climate change. It presents significant threats to the achievement of the Millennium Development Goals especially those related to eliminating poverty, hunger, and promoting environmental sustainability. Forest fruits production is essential to feed a growing population and sustain modern civilization. Climate affects forest trees, a fact well known to every farmer (Enete 2004).

Nigeria is highly vulnerable to effects of climate change; therefore, understanding farmers' responses to climatic variation is crucial, as this will help in designing appropriate coping strategies.

International Institute for Sustainable Development (IISD (International Institute for Sustainable Development), 2007; Lobell et al. 2008) reported that the evidence from past studies has revealed that the recent global warming has influenced agricultural productivity leading to declining food production. IPCC (2007) estimated and suggest that over the next 50 years, climate change may likely have a serious threat to meeting global food needs than other constraints on agricultural systems. The reality of the impact of climate change on agricultural development has started showing signs (Adams et al. 1998; Fischer et al. 2002; Spore 2008), as many of agroforestry species are now characterized with low yield. It was also reported that future impacts will lead to yield losses of crops (Boko et al. 2007).

Presently, most of the original rainforest areas in West Africa has been logged, cleared, and cultivated with arable crops. Recently, a total of 30 plant species producing edible fruits, seeds, and leaves in south-eastern Nigerian rainforest have been reported as endangered (Meregini 2005). Moreover, within the rainforest, 115 plant species whose uses were not classified have been reported as endangered, which could be traced to lack of information even about economically very important tropical rainforest species such as Garcinia kola.

G. kola is a multiple purpose important economic tree growing in forest through west and central Africa and has the potential of improving agroforestry practice; their sustainable use can contribute to regional and local income generation, strengthens food security, improves health care, and increases carbon sequestration to fight climate change. The species is regarded as a wonder plant because every part of the plant (bark, leaves, root, and wood) has been found to be of medicinal importance (Iwu et al. 1990). From its roots to its leaves, the plant is known to contain several phytochemicals noted for their medicinal importance (Iwu et al. 1990). Some of the phytochemical compounds that have been isolated from G. kola include oleoresin class. Others are tannin, saponins, alkaloids, and cardiac glycoside. Farombi and Owoeye (2011) reported antiviral, antihepatotoxic, and antidiabetic properties, while anti-sickle cell disease (antisickling) activities of leaf extracts were revealed by Adejumo et al. (2011).

Its interest is proved as one of the many non-timber forest products that are of high socio-economic importance (Adebisi 2004) and among highest ranked medicinal plants in West Africa in terms of number of recipes in which the species is incorporated (Rai 2003), and investigations proved that G. kola seeds contain compounds useful in curing several diseases. G. kola is growing in popularity as a natural and effective way to help in weight loss programs, and the seed is eaten as refresh past time in Nigeria and has been reported to be used in the manufacture of traditional soft drinks. It is an economically significant and highly valued tree, used extensively in African traditional medicine (Koffi et al. 2015). Many authors have worked on different methods of cultivation of the species by investigating the appropriate methods of seed germination with the aim to encourage its domestication (Agyili et al., 2007; Eyog-Matig et al. 2007; Yakubu et al. 2014, Bolanle - Ojo et al., 2015). They have succeeded in recommending many possible ways of cultivation of G. kola.

Because of high interest in the species resulting in its overexploitation, being over-used, and becoming endangered (IUCN 2004), making the species now close to commercial extinction (Hawthorne 1997; IUCN 2004), it is listed as one of the priority species for immediate conservation action in sub-Saharan forests.

Consequently, there are no orchards or plantations of G. kola in Nigeria. The local farmers are the main stakeholder in its production and little available once are now characterized with low yield; hence, it is necessary to initiate studies aimed at getting insights on farmers' perception in propagation and the impact of climate change on the good and services provided G. kola. 


\section{Materials and methods}

\section{Study area}

Two vegetation zones that cover the ecological range of G. kola in Nigeria, namely, humid forest zone (Rivers, Imo, Abia and Akwa Ibom state) and derived savanna (Oyo, Ekiti, Enugu, and Osun states), were selected for this study (Fig. 1). Each of these zones is characterized by unique vegetation and climatic attributes.

\section{Sampling of farmers}

A sample size of 60 individuals from two vegetation zones (humid and derived savanna zone) was used in a preliminary investigation to determine the proportion of respondents who have observed both changes in temperature and rainfall. Temperature and rainfall were selected for the current study because it is expected that their variation can easily be detected by farmers. Fifty percent of the respondents who have observed both changes in temperature and rainfall were used to calculate the sample size $(N)$ using the formula described by Dagnelie (1998):

$$
\frac{N=U^{2}{ }_{1-\alpha / 2} P(1-p)}{d^{2}}
$$

where $N$ is the total number of households surveyed, i.e., the sample size; $U^{2}{ }_{1-\alpha / 2}$ is the value of the normal random variable for a probability value of ${ }_{\alpha}=0.05 ; U_{1-\alpha / 2}=$ 1,$96 ; p$ is the estimated proportion of people in the villages who have observed changes in both temperature and rainfall $(p=0.50)$; and $d$ is the expected error margin of any parameter to be computed from the survey, which was fixed at 0.05 . Then, from this formula, the sample size $(N)$ was estimated at 215 farmers for all the sites. Hence, 215 farmers were used in this study.

\section{Interview section}

The survey was conducted using semi-structured interviews (Ango et al. 2014 and Elwood 2010) in a form of focus group discussion. The farmers were randomly selected based on age, farm size, and empirical knowledge of G. kola (Tardío et al. 2005); the farmers were carefully interviewed in each village visited, and local interviewers conducted face-to-face interviews with farmer. During the interview, questions were asked about their knowledge on

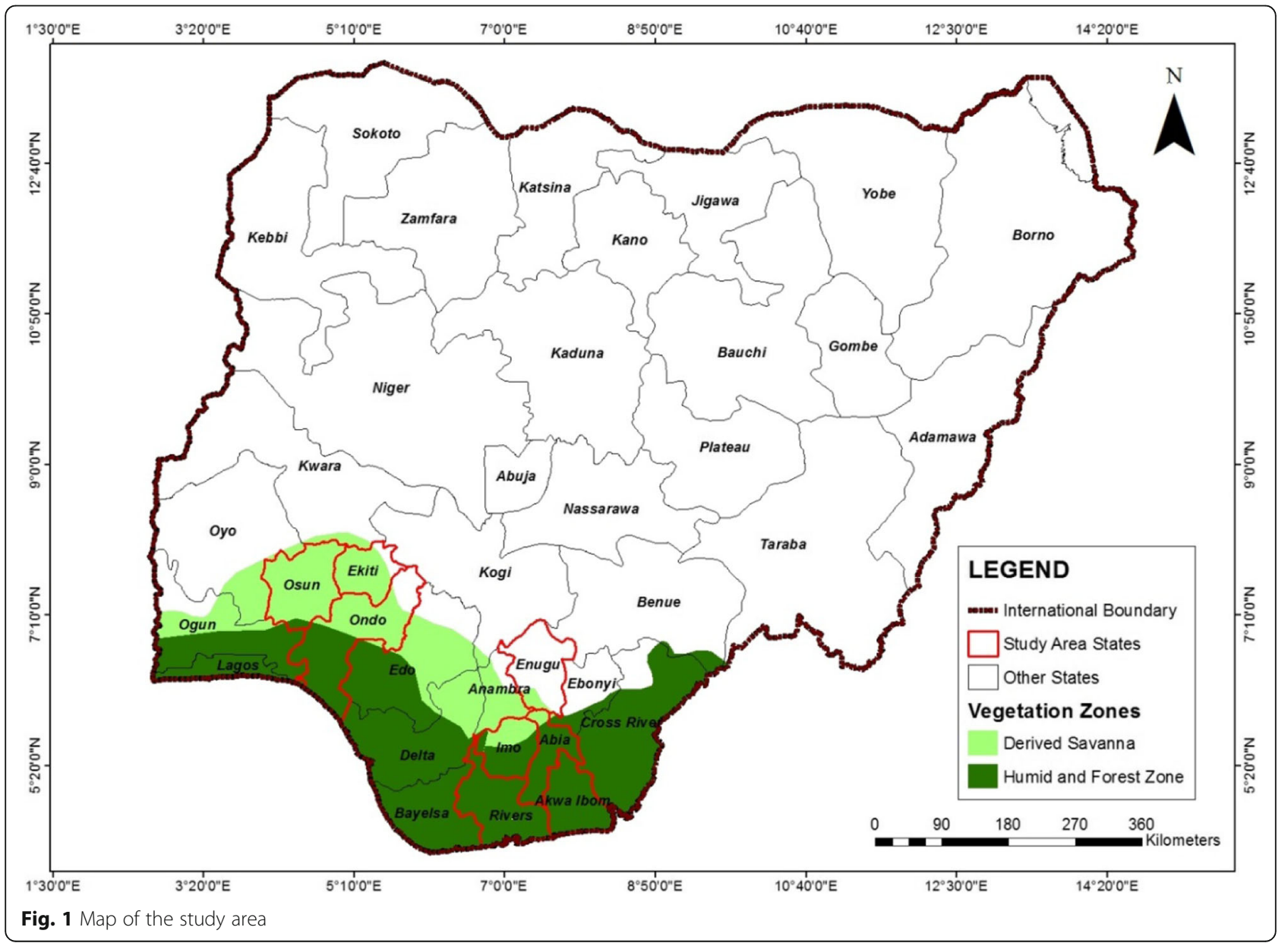


climate change, causes and drivers of climate change, how climate change affects the G. kola fruits, cultivation methods of G. kola, and interest in cultivating species.

\section{Data collection}

A structured interview was also carried out in order to collect information on households' characteristics and their perception of climate change toward the goods and services provided by G. kola. More precisely, questions were asked to ascertain whether farmers had observed changes in some selected indicators such as temperature, rainfall, drought, floods, winds, and length of rainy season and consequences of these changes on G. kola.

\section{Statistical data analysis}

Descriptive statistics were used to analyze farmers' perception of climate change, whereas chi-squared test was used to determine farmers' perception on propagation of G. kola whether there is a significant difference in the perception between the farmers' demography background. A multinomial logit (MNL) regression was used to identify the main determinants of farmers' perception of climate change. The advantage of the multinomial logit is that it permits the analysis of decisions across more than two categories allowing the determination of choice probabilities for different categories of climate attributes. Apart from the well-known drawbacks of the independence of irrelevant alternatives (IIA), this approach is more appropriate than the probit or logit models that have conventionally been used. Instead of having two dichotomous alternatives $(0,1)$ as in the multivariate logit or probit models, the multinomial logit has $\mathrm{J}$ possible states or categories (Cramer 2003; Tse 1987).

To describe the MNL model, let $y$ denote a random variable taking on the values $\{1,2 \ldots$.$\} for choices J$, a positive integer, and let $x$ denote a set of conditioning variables. In this case, $y$ represents the category chosen by any farmers in the study sites. Therefore, $y$ represents a number of climate attributes (temperature, floods, droughts, rainfall, and wind and dust) and $x$ the vector of farmers' characteristics (gender, age, marital status, household size, and educational level). All data collected were analyzed using the SPSS Version 20 and R software Version 3.1.0.

\section{Results}

\section{Respondent demographic background}

The result on the demographic background of the respondents is presented in Table 1. Majority of the respondents were females (56.7\%) while about $43 \%$ were males. About $36.3 \%$ of the respondents were within the age range of 31 to 40 years (28.4) followed by the 41 to 50 age range, while the respondents of above 60 years $(11.6 \%)$ of age had the least frequency (Table 1). From
Table 1 Respondent demographic background

\begin{tabular}{|c|c|c|}
\hline Respondents & Frequency & Percentage \\
\hline \multicolumn{3}{|l|}{ Gender } \\
\hline Male & 93 & 43.3 \\
\hline Female & 122 & 56.7 \\
\hline Total & 215 & 100 \\
\hline \multicolumn{3}{|l|}{ Age range } \\
\hline $21-30$ years & 34 & 15.8 \\
\hline $31-40$ years & 78 & 36.3 \\
\hline $41-50$ years & 61 & 28.4 \\
\hline $51-60$ years & 17 & 7.9 \\
\hline$\geq 60$ years & 25 & 11.6 \\
\hline Total & 215 & 100 \\
\hline \multicolumn{3}{|l|}{ Marital status } \\
\hline Married & 190 & 88.4 \\
\hline Single & 16 & 7.4 \\
\hline No response & 9 & 4.2 \\
\hline Total & 215 & 100 \\
\hline \multicolumn{3}{|l|}{ Number of children } \\
\hline$\leq 2$ & 40 & 18.6 \\
\hline $2-4$ & 53 & 24.7 \\
\hline $5-7$ & 68 & 31.6 \\
\hline No response & 54 & 25.1 \\
\hline Total & 215 & 100 \\
\hline \multicolumn{3}{|l|}{ Highest level of education } \\
\hline No formal education & 7 & 3.3 \\
\hline Post-secondary education & 25 & 11.6 \\
\hline Primary education & 51 & 23.7 \\
\hline Secondary education & 132 & 61.4 \\
\hline Total & 215 & 100 \\
\hline \multicolumn{3}{|l|}{ Occupation } \\
\hline Farming & 106 & 49.3 \\
\hline Trading & 55 & 25.6 \\
\hline Civil servant & 42 & 19.5 \\
\hline No response & 12 & 5.6 \\
\hline Total & 215 & 100 \\
\hline
\end{tabular}

the field survey, it was observed that about $88 \%$ of the respondents were married while the lesser percentage representing the single villagers, though about $4.2 \%$ reported nothing as to their marital status (Table 1) among all the households, the number of children range from two (2) to seven (7). Nevertheless, about $74.9 \%$ of the respondents reported not having any child. From the survey, it shows that the majority of the respondents have secondary education $(61.4 \%)$ while those with primary educational experiences account for about $23.7 \%$ of the respondents (Table 1). It was noticed that the primary 
occupation of the respondents were farming (49.3\%), trading (25.6\%), and public service (19.5\%) with only about $5.6 \%$ elated no clear picture of their primary occupation.

\section{Ownership and location of $G$. kola trees}

From all the 215 respondents assessed, majority of about 73\% own G. kola and are located in farm land, home gardens, fallowed field, and around (Additional file 1: Table S3).

\section{Farmer's willingness to propagate $G$. kola}

Over $91 \%$ of these farmers are presently not cultivating G. kola trees on their farms (Additional file 1: Table S1), though fairly high percentages of the farmers were indecisive on their decision to be cultivating the fruit tree. About $58 \%$ of the farmers would like to cultivate G. kola trees on their farm estate. In combating the unwillingness of the respondents to raising G. kola, information about the new improve methods and possibilities of raising G. kola that was recommended by Agyili et al. (2007), Yakubu et al. (2014), and Bolanle - Ojo et al., $(2014,2015)$ was not spread across them. Over 93\% of these farmers were not aware of these new improved methods. The only way it grows is by natural regeneration which is poor, and the seedlings are uncommon and are characterized with slow growth rate.

Though virtually all the respondents knew nothing about any linkage that may exist between the research institute and the farmers in cultivation of G. kola with the new technological improvement, with the support of the new technology, about $80 \%$ of the farmers are willing to cultivate G. kola. About $96 \%$ of respondents also affirmed that climatic factors such as temperature and precipitation affect or influence the raising of G. kola, but all of their responses showed no indication of how climate affected the fruit tree. Among all the climatic effects, change in rainfall pattern, drought, flood, and temperature are the most significant (Fig. 2). Over 61\% of the respondents reported an increase in the frequency of drought (61.9\%), floods (82.8\%), and temperature (79.1\%) (Additional file 1: Table S3). Other important factor is the trend of wind and dust that is increasing over the years. With about $48 \%$ decrease in the rate of wind and dust, $85.6 \%$ noticed increase in temperature.

\section{Farmers' perception of demands and factors affecting the availability of $\mathrm{G}$. kola}

According to the respondents, the reason for their not cultivating the species was mainly associated with its difficulty (36.7\%) in raising the fruit tree (Additional file 1: Table S2). Other major reasons include difficulty and poor germination rate $(21.9 \%)$ and the problem due to climatic instability (15.8\%).

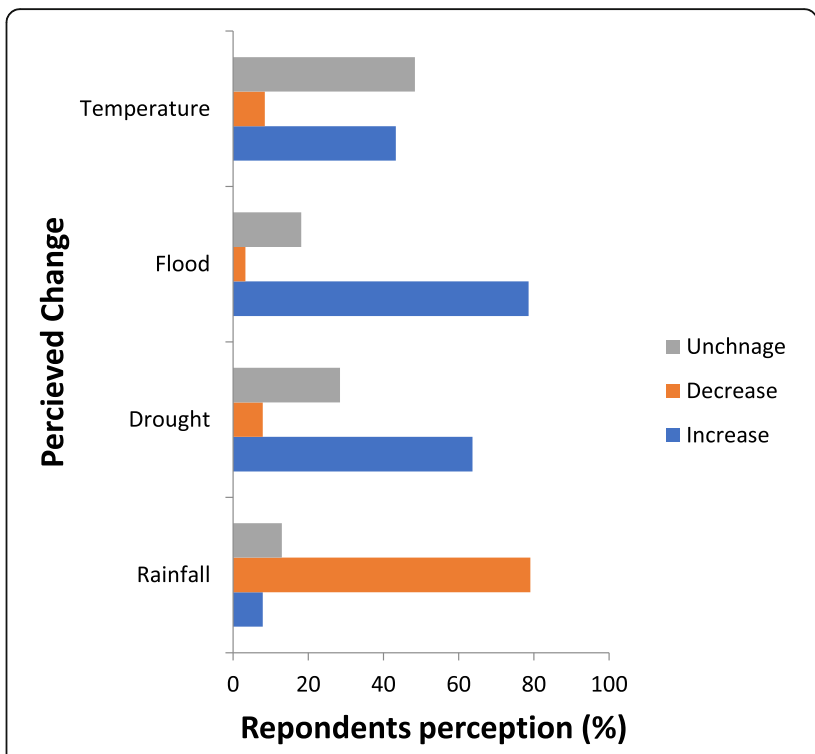

Fig. 2 Farmer's perceptions of climate change

Perception of local income generation of G. kola fruits About $92 \%$ of the farmers generate less than 50,000 from the sale of G. kola fruits from a single tree in a fruiting period while about $8 \%$ of the respondents made between 50,000- 100,000 from a single tree of G. kola in a fruiting tree season (Additional file 1: Table S2).

According to the respondent, the fruiting system is greatly influenced by seasonal variability and these could be accounted for by various factors affecting the forest fruit tree pricing system. Some of the factors reported to be influencing prices of G. kola are the fruit size in combination with seasonal variation (37.2\%), seasonal variation (19.1\%), and fruit test, fruit size, and seasonal variability and deforestation (11.6\%). Descriptive statistic shows that the trend of demand for G. kola fruits is increasing (about $80 \%$ ). With the recent climatic variations, most of the respondents (85.6\%) have noticed the effects of varying temperatures and rainfall pattern on G. kola. Over $67 \%$ of the respondents indicated that consumers desire the G. kola fruits, though the urge of consumption by different consumers may range from its high medicinal values $(38.6 \%)$, taste, nutritive value, and price. Furthermore, with the ready markets (85.1\%) for the G. kola fruit, the standing trees have not been able to satisfy the current demand by consumers (Additional file 1: Table S2).

Most of the respondents (about 97\%) agreed that the tree benefits the environment and ecosystem. The benefits vary from microclimate amelioration (8.8\%), windbreak, esthetic values, shading, and control soil erosion among others. In addition, G. kola trees also have cultural and social benefits in the communities. 
The parts of G. kola were reported by the respondents to provide medicinal advantages, though none of the medicinal properties of the tree was revealed but the dosages adopted by the villagers in catering for different type of disease. The dosages range from one to three times daily among others where other medicinal plant parts are added during the preparation of the medicinal concoctions.

\section{Perception of respondent on propagation ability and demand of G. kola}

The results on perception of respondent on the cultivation of G. kola are presented in Table 2. Apart from sex, all the explanatory variables were significantly associated with farmer's perception of propagation of G. kola in Nigeria. Chi-square analysis revealed that variables such as age, marital status, education level, house-hold size, and primary occupation are the main factors significantly influencing farmers' perception on the cultivation of the G. kola. In contrast, other variables such as sex had no statistical effect on farmer's perception in Nigeria. The study shows that respondent age range determined their perception to future trend of demand for G. kola fruits and their willingness to raise G. kola if encouraged to adopt the new technology; age also influences their perception if temperature and rainfall likely influence germination and availability of G. kola, while the respondent age range does not determined their awareness of the new technology in raising G. kola seedlings. Marital status and household size influence farmers' perception and willingness to raise G. kola if they are encourage and are given the new technology, and respondent educational level and primary occupation influence the respondents' perception to the future trend of demand for G. kola fruits and their willingness to raise G. kola if they are encourage and are given the new technology. It also influences their perception if temperature and rainfall likely influence germination and availability of G. kola.

\section{Multinomial logistic regression (general farmers' perception on climate change)}

Table 3 shows the multinomial logit results of how farmers perceive variation in the selected variables as a result of changes in climate in the study area.

It appears that all the five explanatory variables are significantly associated with G. kola farmer's perception of climate change in Nigeria (Table 3); the multinomial logit analysis revealed that variables such as age, gender, marital status, education level, and household size are the main factors significantly influencing farmers' perception of climate change. The results show that aged farmers indicate an increase in flood, drought, temperature, and strong wind and decrease in rainfall pattern as a result of climate change. When considering the ages of the farmers, the results show that the young active and adult active farmers were able to perceive the changes in climatic variables compared to the older farmers. The probability of observing changes in climatic events increased with educational level of the farmer. Thus, farmer with higher education perceived an increase in the following climatic variables: drought, floods, temperature, and wind in Nigeria, whereas a change in rainfall pattern was observed to be decreasing. Gender and household size perception of changes in climatic variables (drought, floods, temperature, wind, and rainfall) was significantly different within the study area. Male farmers were more likely to perceive the changes in climatic variables compared to female farmers at both sites.

\section{Farmer's perceptions of causes and drivers of climate change}

Even though about $85.6 \%$ of the respondents were aware of climate change, about $90 \%$ of them were unaware of the basic drivers and causes of climate change, and the remaining $10 \%$ attributed the causes of climate change to either deforestation and human behavior or believed climate change is as a result of God's will.

\section{Discussion}

Farmers' perceptions on propagation on G. kola in Nigeria

According to the respondents, the farmers explain the reason for their not propagating the G. kola tree was mainly associated with its difficulty in raising the fruit tree, poor germination rate, and the problem of climatic instability. Many of the farmers gives their view that it is impossible to propagate G. kola and most of the farmers still believes that it is only God that can make G. kola to germinate; all the standing trees of G. kola were inherited from there grandparent.

Despite all the research activities from the academic and research institute on the germination of G. kola, Yakubu et al. (2014) document the success of vegetative propagation of G. kola, and they reported above $85 \%$ success of grafting. Bolanle-Ojo et al. (2014) revealed the possibilities of breaking seed dormancy of G. kola by soaking in water for $72 \mathrm{~h}$ to enhance the rate of germination. Kouakou et al. (2016) reported propagation of G. kola by stem and root cuttings, and they document that IBA treatments promoted shoot and root production and accelerated the emergence of shoots and leaves. All these information about the new technology in cultivating G. kola was not spread across farmers communities. Over $93 \%$ of these farmers were not aware of this new technology. The only means the rural farmers cultivate G. kola is by picking the wildling around the forest area or close to the mother tree. 
Table 2 Perception of respondent on propagation ability of G. kola

\begin{tabular}{|c|c|c|c|c|}
\hline Items & Factors & Df & $x^{2}$ values & $P$ value \\
\hline \multirow[t]{6}{*}{ Ownership G. kola } & A & 4 & 18.167 & $0.001^{*}$ \\
\hline & S & 1 & 0.001 & $0.978^{\text {ns }}$ \\
\hline & MS & 1 & 44.266 & $0.000^{*}$ \\
\hline & $\mathrm{HS}$ & 2 & 5.074 & $0.079^{\text {ns }}$ \\
\hline & $\mathrm{EL}$ & 3 & 33.221 & $0.000^{*}$ \\
\hline & $\mathrm{PO}$ & 2 & 51.870 & $0.000^{*}$ \\
\hline \multirow[t]{6}{*}{ Future demand of fruits } & A & 8 & 71.212 & $0.000^{*}$ \\
\hline & S & 2 & 1.197 & $0.550^{\mathrm{ns}}$ \\
\hline & MS & 2 & 3.585 & $0.167^{\text {ns }}$ \\
\hline & $\mathrm{HS}$ & 4 & 39.569 & $0.000^{*}$ \\
\hline & EL & 30 & 238.876 & $0.000^{*}$ \\
\hline & $\mathrm{PO}$ & 4 & 22.823 & $0.000^{*}$ \\
\hline \multirow[t]{6}{*}{ Currently current of G. kola tree } & $A$ & 4 & 3.502 & $0.478^{\text {ns }}$ \\
\hline & S & 1 & 2.617 & $0.106^{\mathrm{ns}}$ \\
\hline & MS & 1 & 0.768 & $0.381^{\mathrm{ns}}$ \\
\hline & $\mathrm{HS}$ & 2 & 3.065 & $0.216^{\mathrm{ns}}$ \\
\hline & EL & 2 & 5.946 & $0.051^{*}$ \\
\hline & $\mathrm{PO}$ & 2 & 2.210 & $0.331^{\mathrm{ns}}$ \\
\hline \multirow[t]{6}{*}{ Awareness of new technology of cultivation } & A & 4 & 1.745 & $0.782^{\mathrm{ns}}$ \\
\hline & S & 1 & 0.453 & $0.501^{\mathrm{ns}}$ \\
\hline & MS & 1 & 0.634 & $0.426^{\mathrm{ns}}$ \\
\hline & HS & 2 & 3.939 & $0.140^{\mathrm{ns}}$ \\
\hline & EL & 2 & 4.171 & $0.124^{\mathrm{ns}}$ \\
\hline & $\mathrm{PO}$ & 2 & 3.294 & $0.193^{\mathrm{ns}}$ \\
\hline \multirow[t]{6}{*}{ Willingness to adopt the new technology } & A & 4 & 154.214 & $0.000^{*}$ \\
\hline & S & 1 & 1.106 & $0.293^{\mathrm{ns}}$ \\
\hline & MS & 1 & 14.046 & $0.000^{*}$ \\
\hline & $\mathrm{HS}$ & 2 & 22.305 & $0.000^{*}$ \\
\hline & EL & 2 & 151.699 & $0.000^{*}$ \\
\hline & $\mathrm{PO}$ & 2 & 57.624 & $0.000^{*}$ \\
\hline \multirow[t]{6}{*}{ Awareness of climate influence on germination } & A & 4 & 138.844 & $0.000^{*}$ \\
\hline & S & 1 & 3.473 & $0.062^{\text {ns }}$ \\
\hline & MS & 1 & 1.418 & $0.234^{\mathrm{ns}}$ \\
\hline & HS & 2 & 57.473 & $0.000^{*}$ \\
\hline & EL & 2 & 15.621 & $0.000^{*}$ \\
\hline & $\mathrm{PO}$ & 2 & 23.221 & $0.000^{*}$ \\
\hline
\end{tabular}

* Significant differences at $p<0.05,{ }^{\text {ns }}$ not significant differences

$A$ age, $S$ sex, Ms marital status, HS household size, EL educational level, $P O$ primary occupation

Though virtually all these respondents knew nothing about any linkage that may exist between the research institute and the farms in raising G. kola with the new technological improvement, with the support of the government agencies, many of the farmers are willing to cultivate the G. kola.
Farmers' perceptions on the impacts climate change on goods and services provided by $\mathrm{G}$. kola

All the farmers' interviewed across farmer villages agreed that climatic variability influences the availability of G. kola which in turn has significant effects on the good and services provided to the people. Most of the 
Table 3 Results of multinomial regression of G. kola farmer's perceptions of climate change according to some explanatory variables

\begin{tabular}{lll}
\hline Covariance & Decrease & Unchanged \\
\hline (A) Perception variable = rainfall & \\
Number of observation & 215 & \\
Residual deviance & 230.741 & \\
AlC & 254.741 & \\
Pseudo $R^{2}$ & 0.172 & $2.261(0.764)^{* * *}$ \\
Age & $2.545(0.649)^{* * *}$ & $0.375(0.806)$ \\
Sex & $0.955(0.669)^{*}$ & $0.553(1.051)$ \\
Marital & $-0.612(0.944)$ & $-0.020(0.572)$ \\
Household_size & $-0.222(0.446)$ & $1.511(0.584)^{* * *}$ \\
Educational_level & $1.348(0.399)^{* * *}$ &
\end{tabular}

(B) Perception variable $=$ drought

$\begin{array}{lll}\text { Number of observation } & 215 & \\ \text { Residual deviance } & 292.163 & \\ \text { AIC } & 316.163 & \\ \text { Pseudo } R^{2} & 0.089 & \\ \text { Age } & -0.060(0.501) & -0.536(0.351)^{*} \\ \text { Sex } & -0.671(0.573) & 0.044(0.425) \\ \text { Marital } & 0.864(0.892) & -0.178(0.716) \\ \text { Household_size } & 0.313(0.501) & -0.260(0.318) \\ \text { Educational_level } & -1.096(0.425)^{* * *} & -1.138(0.298)^{* * *} \\ \text { C) Perception variable }=\text { flood } & & \\ \text { Number of observation } & 215 & \\ \text { Residual deviance } & 279.317 & \\ \text { AlC } & 303.317 & \\ \text { Pseudo } R^{2} & 0.089 & -0.532(0.351)^{*} \\ \text { Age } & -0.019(0.517) & -0.044(0.412) \\ \text { Sex } & 0.463(0.679) & 0.713(0.582) \\ \text { Marital } & -8.187(66.418) & -0.175(0.320) \\ \text { Household_size } & 0.013(0.514) & -0.946(0.296)^{* * *} \\ \text { Educational_level } & -1.234(0.448)^{* *} & \end{array}$

(D) Perception variable $=$ temperature

$\begin{array}{lll}\text { Number of observation } & 215 & \\ \text { Residual deviance } & 366.924 & \\ \text { AIC } & 390.924 & \\ \text { Pseudo } R^{2} & 0.051 & \\ \text { Age } & 0.173(0.356) & 0.293(0.385) \\ \text { Sex } & -0.041(0.392) & 0.877(0.493)^{*} \\ \text { Marital } & 0.974(0.552)^{* *} & 0.176(0.847) \\ \text { Household_size } & -0.526(0.309)^{*} & -0.238(0.365) \\ \text { Educational_level } & -0.059(0.299) & -0.626(0.320)^{* *}\end{array}$

(E) Perception variable $=$ wind

Number of observation $\quad 215$
Table 3 Results of multinomial regression of G. kola farmer's perceptions of climate change according to some explanatory variables (Continued)

\begin{tabular}{lll}
\hline Covariance & Decrease & Unchanged \\
\hline Residual deviance & 368.322 & \\
AIC & 392.322 & \\
Pseudo $R^{2}$ & 0.051 & \\
Age & $-0.233(0.504)$ & $-0.454(0.291)^{*}$ \\
Sex & $0.809(0.622)^{*}$ & $0.363(0.344)$ \\
Marital & $1.917(0.770)^{*}$ & $1.029(0.589)^{*}$ \\
Household_size & $0.369(0.479)$ & $0.428(0.264)^{*}$ \\
Educational_level & $-0.256(0.461)$ & $-0.556(0.255)^{* *}$ \\
\hline
\end{tabular}

$* * * * * *$ Significant at 1,5 and $10 \%$ probability level, respectively

farmers reported that the Harmattan season influences fruiting ability of G. kola trees, and increase in Harmattan season usually leads to increase in fruits production of G. kola. Though many of them do not have clear understanding on the mechanism on how climate influences the species, but they identify climatic factors such as drought, flood, variability in rainfall pattern, and increase in temperature as the most significant sign. Over $61 \%$ of the respondents reported an increase in the frequency of drought (61.9\%), floods (82.8\%), and temperature $(79.1 \%)$.

The finding shows that farmers are well aware of climate change and its effects such as change in rainfall patterns, frequent drought and floods, increase in temperature, and stronger winds; the results corroborate as reported by Kapoury et al. (2016). They studied farmer's perception of climate change in southern Mali and reported increases in the frequency of strong wind, dust, drought, high temperatures, and number of hot days as the main climate change-related indicators, and an early cessation of the rainy season, frequent drought, and wind the factors impeding a better delivery of the ecosystem services from the parklands. Similar findings were reported by Ayanwuyi et al. (2010), Mertz et al. (2009), Odewumi et al. (2013), Sofoluwe et al. (2011), and Mengistu (2011).The results also agree with Rashman (2006) who reported that high temperatures are often associated with drought while increase in temperature is expected to reduce crop yields and increase levels of food insecurity (IPCC, 2007; Ogalleh et al. 2012).

A chi-square analysis showed no significant difference in farmers' perceptions about climate change between the study area indicating that their knowledge might be similar. This agrees with Odewumi et al. (2013), who observed no significant difference in farmers' perceptions of climate change between two sites in Nigeria. 
Results of multinomial regression of G. kola farmer's perceptions of climate change according to some explanatory variables in Southern Nigeria

The results of multinomial logit regressions show that age, sex, marital status, household size, and education level are the main factors significantly influencing farmers' perception of climate change in study area. This result is consistent with the fact that the socio-demographic characteristics influence farmers' perception of climate change as reported by previous authors (Kapoury et al. 2016; Ayanwuyi et al. 2010; Legesse et al. 2010; Olayemi 2012; Sahu and Mishra 2013). This result is however in contrast to the findings of Odewumi et al. (2013), who found no influence of any of the explanatory variables (age, education level, and gender) on farmers' perception of climate change.

The results of the logit regression suggest that age of farmers is also a good predictor associated with the farmers' perception of the continuous decrease and no change in rain fall pattern, drought, flood, temperature and winds in Nigeria. Indeed, older farmers have been exposed more to changes in the climate than the younger farmers; the result is in agreement as reported by Kapoury et al. 2016), Nhemachena et al. (2007), and Varadan et al. (2014), but the findings contradicts that reported by Sahu and Mishra (2013). The educational level of farmers is also a good predictor associated with the farmers' perception of the occurrence and stability of decrease and no change in rain fall pattern, drought, flood, temperature, and winds in Nigeria. Better educated farmers perceived climate changes more because they have several ways to document and remember past events (Habiba et al. 2012).

\section{Conclusion}

Nigeria is a country marked with ecological diversity and climatic contrasts with diverse biophysical characteristics, ethnic nationalities, agro-ecological zones, and socio-economic conditions. Pressure from growing population results in diminishing resources, further threatening food production, and instability of climatic conditions increase the suffering and poverty with people unable to live in their homes and their sources of income destroyed. This study investigates the farmers' perceptions on propagation and the impacts of climate change on goods and services provided by G. kola in Nigeria. The results show that farmers are not currently propagating G. kola and most of the available stands were inherited from grandparents; this could be mainly associated with its difficulty in raising the species, poor germination rate, and the problem of climatic instability. Despite all the research activities from the academic and research institute in Nigeria on the germination of $G$. kola, information about the new technology in raising $G$. kola was not spread across farmers' communities; majority of these farmers were not aware of this new technology. Efforts should be made by government agencies to initiate program to educate the rural farmers on propagation possibilities, potential ecosystem services, and the impact of climate change on multiple purpose agroforestry species such as G. kola.

\section{Additional file}

Additional file 1: Table S1. Farmer's willingness to plant G. kola. Table S2. Farmers' perception of demands and factors affecting the availability of $G$. kola. Table S3. Ownership and location of G. kola trees. (DOCX 18 kb)

\section{Acknowledgements}

The authors wish to express their sincere gratitude to thank the farmers and local administrators of the study area for their assistance during the field work and the West African Climate Change and Adapted Land-use programme funded by German Federal Ministry for Education and Research for providing financial support to the corresponding author to carry out this research. Thanks to the head of station and all the technical staff of Moist Research Station of Forestry Research Institute of Nigeria, and we specially appreciate Mr. Olumide Babalola.

\section{Funding}

The study was funded by West African Climate Change and Adapted Land use programme through the German Federal Ministry for Education and Research.

Availability of data and materials

Will be made available upon request.

\section{Authors' contributions}

SP and BA conceived the project idea. AOP prepared the research instruments which were modified by JSO. AOP collected all the necessary data and analyzed and drafted the manuscript, guided and supervised by BA, JSO, and SP. All co-authors reviewed and discussed the results, helped in the interpretation of the results, and contributed to the draft and final manuscript. All authors read and approved the final manuscript.

Ethics approval and consent to participate

Not applicable.

Consent for publication

Not applicable.

Competing interests

The authors declare that they have no competing interests.

\section{Publisher's Note}

Springer Nature remains neutral with regard to jurisdictional claims in published maps and institutional affiliations.

\section{Author details}

${ }^{1}$ WASCAL Graduate Research Program on Climate Change and Biodiversity, Universite' Felix Houphouet Boigny, BP 165, Abidjan 31, Côte d'Ivoire.

${ }^{2}$ Centre Suisse de Recherches Scientifiques en Côte d'Ivoire (CSRS), Université Nangui Abrogoua, Abidjan, Côte d'Ivoire. ${ }^{3}$ Department of Social and Environmental Forestry, University of Ibadan, Ibadan, Nigeria. ${ }^{4}$ Institute for Biodiversity Research, University of Rostock, Rostock, Germany.

Received: 15 June 2018 Accepted: 25 October 2018

Published online: 29 November 2018

\section{References}

Adams R, Brian H, Stephanie L, Leary N (1998) Effects of global climate change on agriculture: an interpretative review. Clim Res 11:19-30 1998 
Adebisi AA (2004) A case study of $G$. kola nut production-to consumption system in J4 area of Omo forest reserve, South-west Nigeria. In: Sunderland T, Ndoye $\mathrm{O}$ (eds) Forest products, livelihood and conservation (case study of nontimber Forest product systems), volume 2 Africa, pp 115-132

Adejumo OE, Ayoola MD, Kolapo AL, Orimoyegun VO, Olatunji PO (2011) Antisickling activities of extracts of leaf, seed and seed pod of $G$. kola Heckel. Afr. J. Pharm. Pharmacol 5(1):48-52. https://doi.org/10.5897/AJPP10.052

Agyili J, Sacande M, Koffi E, Peprah T (2007) Improving the collection and germination of West African G. kola Heckel seeds. New For 34(3):269-279. https://doi.org/10.1007/s11056-007-9054-7

Ango TG, Börjeson L, Senbeta F, Hylander K (2014) Balancing ecosystem services and disservices: smallholder farmers' use and management of forest and trees in an agricultural landscape in southwestern Ethiopia. Ecol Soc 19(1):30. https://doi.org/10.5751/ES-06279-190130T.O. and Babalola, FD. (eds). Proceedings of Nigeria Tropical Biology Association (NTBA). 5th Annual Biodiversity Conference, FUTA, pp. 52-57

Ayanwuyi E, Kuponiyi FA, Ogunlade I, Oyetoro JO (2010) Farmer's perception of impact of climate changes on food crop production in Ogbomoso agricultural zone of Oyo state, Nigeria. Glob J Hum Soc Sci 10:33-39

Boko M, Niang I, Nyong A, Vogel C, Githeko A, Medany M (2007) Africa. In: Parry ML, Canziani OF, Palutikof JP, Van der Linden PJ, Hanson CE (eds) Climate change (2007) impacts, adaptation and vulnerability. Contribution of working group II to the fourth assessment report of the intergovernmental panel on climate change. Cambridge University Press, Cambridge, pp 433-467

Bolanle - Ojo OT, Afolabi JO, Fapojuwomi OA (2015) Domestication of G. kola Heckel: effect of light intensities on early growth performance. In: Conservation in 21 st century Nigeria: transcending disciplinary boundaries

Bolanle - Ojo OT, Ogunade JO, Williams OA, Ajekigbe JM (2014) Biomass accumulated by G.kola Heckel. Seedlings under different light intensities. J Agric For Soc Sci 2(12):159-165

Cramer JS (2003) Logit models from economics and other fields. Cambridge University Press, New York, p 185

Dagnelie P (1998) Statistiques théoriques et appliquées. De Boeck, Brussels, p 517

Deressa TR, Hassen T, Alemu M, Yesuf RC (2008) Analyzing the determinants of farmers' choice of adaptation measures and perceptions of climate change in the Nile Basin of Ethiopia, International Food Policy Research Institute (IFPRI) Discussion Paper No. 00798. IFPRI, Washington, DC

Dinar A, Hassan R, Kurukulasuriya P, Benhin J, Mendelsohn R (2006) The policy nexus between agriculture and climate change in Africa. A synthesis of the investigation under the GEF/WB Project: Regional climate, water and agriculture: impacts on and adaptation of agro-ecological systems in Africa. CEEPA Discussion Paper No. 39. Centre for Environmental Economics and Policy in Africa, University of Pretoria

Elwood S (2010) Mixed methods: thinking, doing, and asking in multiple ways. In: DeLyser D, Herbert S, Aitken SC, Crang M, McDowell L (eds) The SAGE handbook of qualitative geography. SAGE, Los Angeles, California, USA, pp 94-115. https://doi.org/10.4135/9780857021090.n7

Enete IC (2004) A study of Enugu rainfall patterns from the viewpoint of precipitation dynamics. Publish by Journal of Earth Science \& Climatic Change. J Res Prod 5:1-4. https://doi.org/10.4172/2157-7617.1000234

Eyog-Matig O, AKN A, Linsoussi C (2007) G.kola Heckel seeds dormancy-breaking. Appl Ecol Environ Res 5(1):63-71. https://doi.org/10.15666/aeer/0501_063071

Farombi EO, Owoeye O (2011) Antioxidative and chemopreventive properties of Vernonia amygdalina and Garcinia biflavonoid. Int J Environ Res Public Health 8(6):2533-2555. https://doi.org/10.3390/ijerph8062533

Fischer G, Shah M, van Velthuizen H (2002) "Climate change and agricultural vulnerability". International Institute for Applied Systems Analysis. Report prepared under UN Institutional Contract Agreement 1113 for World Summit on Sustainable Development. Laxenburg, Austria

Habiba U, Shaw R, Takeuchi T (2012) Farmer's perception and adaptation practices to cope with drought: perspectives from Northwestern Bangladesh. Int J Disast Risk Reduct 1:72-84

Hawthorne WD (1997) Garcinia kola. In: IUCN 2003. 2003 IUCN Red List of Threatened Species

IISD (International Institute for Sustainable Development) (2007) Community based adaptation to climate change bulletin. A summary of the second international workshop on community-based adaptation to climate change. IISD Reporting Services

IPCC (2007) Climate change: synthesis report. Contribution of working groups I, II and III to the Fourth Assessment Report of the Intergovernmental Panel on Climate Change. Intergovernmental Panel on Climate Change, Geneva, p 52
IPCC (2014) Summary for policymakers. In: Climate change 2014: impacts, adaptation, and vulnerability. Part A: Global and sectoral aspects. Contribution of Working Group II to the Fifth Assessment Report of the Intergovermental Panel on Climate Change [Field CB, Barros VR, Dokken DJ, Mach KJ, Mastrandrea MD, Bilir TE, Chatterjee M, Ebi YL, Estrada YO, Genova RC, Girma B, Kissel ES, Levy AN, MacCracken S, Mastrandrea PR, White LL (eds)]. Cambridge University Press, Cambridge and New York. pp 1-32

IUCN (the World Conservation Union) (2004) IUCN Red List of Threatened Species. World Conservation Press. [also searchable database at http://www. unepwcmc.org/trees/background/afric a.htm; accessed June 2004].

Iwu MM, Igbokao OA, Okunji S, Tempesta MS (1990) Antidiabetic and aldose reductase activities of biflavanones of $G$. kola. J Pharm Pharmacol 42:290-292

Kapoury S, Joachim B, Jules B, Grace B Villamor, Antoine K and Dodiomon S (2016) Farmers' perceptions of climate change impacts on ecosystem services delivery of parklands in southern Mali Agroforestry Systems. An International Journal incorporating Agroforestry Forum, ISSN 0167-4366, Agroforest System. https://doi.org/10.1007/s10457-016-9933-z. pp4-17

Koffi EN, Rayner PJ, Norton AJ, Frankenberg C, Scholze M (2015) Investigating the usefulness of satellite-derived fluorescence data in inferring gross primary productivity within the carbon cycle data assimilation system. Biogeosciences 12:4067-4084. https://doi.org/10.5194/bg-12-4067-2015

Kouakou KL, Dao JP, Kouassi Kl, Beugré MM, Koné M, Baudoin JP, Zoro Bi IA (2016) Propagation of G. kola (Heckel) by stem and root cuttings. Silva Fennica 50(4):1588. https://doi.org/10.14214/sf.1588. 17 p

Lobell DB, Burke BM, Tebaldi C, Mastrandrea DM, Falcon PW, Naylor LR (2008) Prioritizing climate change adaptation needs for food security in 2030. Science 319:607-610

Mengistu KD (2011) Farmers' perception and knowledge of climate change and their coping strategies to the related hazards: case study from Adiha, central Tigray, Ethiopia. Agric Sci 2:138-145. https://doi.org/10.4236/as.2011.22020

Meregini AOA (2005) Some endangered plants producing edible fruits and seeds in southeastern Nigeria. Fruits 60(3):211-220

Mertz O, Mbow C, Reenberg A, Diouf A (2009) Farmer's perceptions of climate change and agricultural strategies in rural Sahel. J Environ Manag 4:804-816. https://doi.org/10.1007/s00267-008-9197-0

Nhemachena C, Hassan R (2007) Micro-level analysis of farmers' adaptation to climate change in Southern Africa. IFPRI Discussion Paper No. 00714. International Food Research Institute, Washington DC

Niang I, Ruppel OC, Abdrabo MA, Essel A, Lennard C, Padgham J, Urquhart P (2014) Africa. In: Climate change 2014: impacts, adaptation and vulnerability. Contribution of Working Group II to the Fifth Assessment Report of the Intergovernmental Panel on Climate Change. Cambridge University Press, Cambridge

Odewumi SG, Awoyemi OK, Iwara Al, Ogundele FO (2013) Farmer's perception on the effect of climate change and variation on urban agriculture in Ibadan Metropolis, South-western Nigeria. J Geogr Reg Plan 6:209-217

Ogalleh SA, Vogl CR, Eitzinger J, Hauser M (2012) Local Perceptions and Responses to Climate Change and Variability: The Case of Laikipia District, Kenya. Sustainability 4(12):3302

Olayemi OD (2012) Determinants of climate change and coping strategies among crop farmers in Ondo state, Nigeria. Agric Res Rev 1:127-131

Rai ND (2003) Human use, reproductive ecology and life history of Garcinia gummi-gatha a non timber forest product, in the Western Gaths, India, Thesis submitted in partial fulfillment of the requirements for the degree of doctor of philosophy. Pennsylvania State University, graduate school, department of Biology, p 191

Rashman H (2006) Number and weight of cotton lint fibres: variation due to high temperature in the field. Aust J Agric Res 57:583-590

Sahu CN, Mishra D (2013) Analysis of perception and adaptability strategies of the farmers to climate change in Odisha, India. APCBEE Procedia 5:123-112

Sofoluwe N, Tijani A, Baruwa O (2011) Farmers' perception and adaptations to climate change in Osun State, Nigeria. Afr J Agric Res 6:4789-4794

SPORE (2008) Climate Change, Spore Special Issue-August, 2008

Tardío J, Pascual H, Morales R (2005) Wild food plants traditionally used in the province of Madrid, Central Spain. Econ Bot 59(2):122-136

Tse YK (1987) A diagnostic test for the multinomial logit model. J Bus Econ Stat 5:283-286

Varadan JR, Kumar P (2014) Indigenous knowledge about climate change: validating the perceptions of dryland farmers in Tamil Nadu. Indian J Tradit Knowl 13:390-397

Yakubu FB, Adejoh OP, Ogunade JO, Igboanugo ABI (2014) Vegetative propagation of G.kola (Heckel). World J Agric Sci 10:85-90 